\title{
Ethanolic Extract of Glycyrrhiza glabra to Ameliorate Oxidative Stress - Studies In vitro
}

\author{
Dhanya K Chandrasekharan ${ }^{1, *(D)}$, Femi Varghese ${ }^{1(D)}$ \\ 1 Department of Microbiology, St. Mary's College, Thrissur, Kerala, India \\ * Correspondence: dhanuchandra@gmail.com;
}

Scopus Author ID 35077534000

Received: 15.10.2020; Revised: 17.11.2020; Accepted: 19.11.2020; Published: 22.11.2020

\begin{abstract}
Plants are major sources of bioactive organic molecules of interest for the pharmaceutical industry and are being screened for new drugs and chemicals. Glycyrrhiza glabra Linn. (Family: Fabaceae) is a very well-known medicinal plant traditionally used as medicine. Its roots and rhizomes are the medicinal parts used and are reported to possess antitumor, antimicrobial, antiviral, antiinflammatory, immunoregulatory activities. The ethanolic extract of Glycyrrhiza glabra was prepared in the present work, and its phytochemical analysis and HPLC were done. The in vitro antioxidant activity assays such as DPPH radical scavenging assay, Hydroxyl radical scavenging assay, total antioxidant activity assay, and total reducing power assay was done, and the results showed significant antioxidant activity. The extract was analyzed further to evaluate the ability to protect against oxidative stress in chicken liver tissue. The extent of lipid peroxidation and glutathione in $\mathrm{H}_{2} \mathrm{O}_{2}$ and/or Glycyrrhiza glabra extract-treated tissue indicated the extract's potential to protect against oxidative stress under in vitro conditions. The in vitro comet assay results showed that the Glycyrrhiza glabra extract protected against $\mathrm{H}_{2} \mathrm{O}_{2}$ induced cellular DNA damage. These findings indicated promising antioxidant and antigenotoxic potential of Glycyrrhiza glabra and need further exploration for translating these findings to its possible health benefits.
\end{abstract}

Keywords: oxidative stress; DNA damage; genotoxicity.

(C) 2020 by the authors. This article is an open-access article distributed under the terms and conditions of the Creative Commons Attribution (CC BY) license (https://creativecommons.org/licenses/by/4.0/).

\section{Introduction}

Plants have been a major source of medicine since ancient times. The demand for herbal medicines is on the increase across the world since herbs have stood the trial of time for their safety and efficacy [1]. Glycyrrhiza glabra Linn. (Family- Fabaceae) is a very well used medicinal plant in traditional medicine systems across the globe. The root and rhizome are the major medicinal parts used. Glycyrrhiza glabra is one of the oldest and most frequently used herbs in traditional Chinese medicine. It is an important part of Indian Traditional Medicine Systems. In recent years, many studies have reported that the active compounds isolated from Glycyrrhiza glabra possess antitumor, antiviral, antimicrobial, immunoregulatory, antiinflammatory, etc. [2,3,4].

The present study aims to study the antioxidant potential of ethanolic extract of Glycyrrhiza glabra and its potential to protect tissue and cellular DNA from oxidative stress under in vitro conditions. 


\section{Materials and Methods}

\subsection{Preparation of ethanolic extract.}

The plant part used in the present study is the root of Glycyrrhiza glabra purchased from the local market. These were ground to get the powder, which was then extracted using ethanol. The concentrated extract was then dried by evaporation, weighed, and stored for further use.

\subsection{Phytochemical analysis.}

The ethanolic extract of Glycyrrhiza glabra was subjected to various qualitative phytochemical screening [5] to test secondary metabolites such as cardiac glycosides and coumarins, quinones, saponins, terpenoids, phlobatannins, steroids, anthraquinones, tannins, phenols, and flavonoids.

\subsection{HPLC analysis.}

HPLC analysis of the extract was done at KFRI, Thrissur, Kerala. The instrument specifications are as follows. Shimadzu system controller: SCL-10Avp, Shimadzu UV/Vis Photodiode array detector: SPD-M10 Avp, Shimadzu solvent delivery pump: LC 10ATvp, Shimadzu column oven: CTO-10ASvp, HPLC Column Luna 5u C18: 250x4.6mm (Phenomenex), Hamilton microsyringe (25ul capacity), Pump mode: Gradient pump, Sample volume required for analysis: $20 \mathrm{ul}$.

\subsection{Antioxidant activity analysis.}

The free radical scavenging potential of the ethanolic extract of Glycyrrhiza glabra was studied using DPPH free radical scavenging assay and Hydroxyl free radical scavenging assay [6]. The total antioxidant capacity was measured according to Preito et al. [7], and the reducing power was determined by the method of Yen and Duh [8].

\subsection{Protection of tissue against oxidative stress under in vitro.}

Chicken Liver tissue homogenate was exposed to $1 \mathrm{mM} \mathrm{H}_{2} \mathrm{O}_{2}$ in the presence or absence of different concentrations of ethanolic extract of Glycyrrhiza glabra for 10 minutes, and the levels of GSH and extent of lipid peroxidation was analyzed as detailed below. Reduced glutathione was determined according to the method of Moron et al., [9] with minor modifications.

$100 \mu \mathrm{L}$ of tissue homogenate was mixed with $63 \mu \mathrm{L}$ of $25 \%$ TCA and cooled on ice for 5 minutes. It was mixed with $300 \mu \mathrm{L}$ of $5 \%$ TCA and then centrifuged at $3000 \mathrm{~g}$ for 5 minutes. $150 \mu \mathrm{L}$ of the supernatant was mixed with $350 \mu \mathrm{L}$ of sodium phosphate buffer $(0.2 \mathrm{M}, \mathrm{pH} 8.0)$ and $1.0 \mathrm{~mL}$ of DTNB (0.6 mM in $0.2 \mathrm{M}, \mathrm{pH} 8.0$ phosphate buffer). The yellow color obtained was measured at $412 \mathrm{~nm}$. A standard graph prepared using different concentrations (10-50 nmoles) of GSH was used to calculate the samples' GSH content in $\mathrm{nmol} / \mathrm{mg}$ protein.

The level of lipid peroxidation was measured as malondialdehyde (MDA) according to the method of Buege and Aust [10]. The peroxidation of PUFAs forms malondialdehyde (MDA). MDA is a TBA reacting substance, and the product formed between MDA and TBA can be estimated at $532 \mathrm{~nm}$. 
Briefly, the reaction mixture contained $1 \mathrm{~mL}$ of tissue homogenate $(100 \mathrm{~mL}$ of $10 \%$ tissue homogenate $+900 \mathrm{~mL}$ distilled water) and $1 \mathrm{~mL}$ of TBA reagent $(0.375 \%$ thiobarbituric acid, $0.025 \mathrm{~N} \mathrm{HCl}, 15 \%$ trichloroacetic acid and $6.0 \mathrm{mM}$ EDTA). The reaction mixture was heated at $90^{\circ} \mathrm{C}$ for 30 minutes, cooled, and centrifuged at 10,000xg for 10 minutes. The amount of TBARS in the supernatant was obtained by measuring the absorption at $532 \mathrm{~nm}$. The lipid peroxidation values are expressed as $n$ moles of MDA per mg protein.1, 1, 3, 3tetraethoxypropane was used as the standard.

Protein content in the tissue was determined according to the method of Lowry et al. [11]. Protein content was calculated from the standard graph plotted using different concentrations $(0-500 \mu \mathrm{g} / \mathrm{mL})$ of bovine serum albumin (BSA).

\subsection{Alkaline single cell gel electrophoresis or Comet assay-in vitro.}

Alkaline single cell gel electrophoresis was performed [12] under in vitro conditions on human peripheral blood leukocytes. The DNA strand breaks were introduced by treatment with $1 \mathrm{~mm} \mathrm{H} \mathrm{H}_{2} \mathrm{O}_{2}$ in human peripheral blood lymphocytes. The extent of DNA damage was measured using alkaline single cell gel electrophoresis. Blood was incubated with $\mathrm{ImM} \mathrm{H}_{2} \mathrm{O}_{2}$ in the presence or absence of different Glycyrrhiza glabra extract $(1 \mathrm{mg} / \mathrm{ml}$ or $2 \mathrm{mg} / \mathrm{ml})$ for 5 minutes. After incubation, the samples were analyzed by comet assay. Microscopic slides were coated with normal melting point agarose, and $200 \mu \mathrm{l}$ of $0.8 \%$ low melting point agarose containing $50 \mu \mathrm{l}$ of treated cells (containing $10^{4}-10^{5}$ cells) were added onto the slide, and the slides were kept at $4 \circ \mathrm{C}$. After solidification, the slides were immersed in a prechilled lysing solution (2.5 $\mathrm{M} \mathrm{NaCl}, 10 \mathrm{mM}$ Tris-HCl, 100 mM Na2EDTA, pH 10, , $1 \%$ TritonX 1\% DMSO) and kept for $1 \mathrm{~h}$ at $4{ }^{\circ} \mathrm{C}$. After lysis, slides were drained and placed in a horizontal electrophoretic apparatus filled electrophoresis buffer $(300 \mathrm{mM} \mathrm{NaOH}, 0.2 \%$ DMSO, $1 \mathrm{mM}$ EDTA, $\mathrm{pH} \geq 13)$. The slides were equilibrated in a buffer for $20 \mathrm{~min}$, and electrophoresis was carried out for 30 min at $20 \mathrm{~V}, 300 \mathrm{~mA}$. After electrophoresis, the slides were washed gently with $0.4 \mathrm{mM}$ Tris$\mathrm{HCl}$ buffer, $\mathrm{pH} 7.4$ followed by distilled water, dried, and silver staining was carried out.

\subsection{Statistical analysis.}

The results are presented as mean \pm SD of the studied groups. Microsoft Excel and GraphPad Prism software were used.

\section{Results and Discussion}

The roots of Glycyrrhiza glabra were collected, shade dried, and powdered. The ethanolic extract was obtained by soxhlet extraction. The extract was evaporated to dryness, and the percentage of yield was found to be $29 \%$.

\subsection{Phytochemical analysis.}

As can be seen from Table 1, the ethanolic extract of Glycyrrhiza glabra contained coumarins, saponins, quinones, cardiac glycosides, terpenoids, phlobatannins, anthraquinones, tannins, phenols, and flavonoids. 
Table 1. Phytochemical analysis of ethanolic extract of Glycyrrhiza glabra, + indicates the presence and indicates absence.

\begin{tabular}{l|l|c} 
Sl.no & Phytochemicals & Ethanolic extract \\
\hline 1 & Coumarins & + \\
\hline 2 & Saponin & + \\
\hline 3 & Quinone & + \\
\hline 4 & Cardiac glycosides & + \\
\hline 5 & Terpenoids & + \\
\hline 6 & Phlobatannins & + \\
\hline 7 & Anthraquinones & + \\
\hline 8 & Tannins & + \\
\hline 9 & Phenols & +
\end{tabular}

The ethanolic extract's phytochemical screening showed that the roots were rich in coumarins, saponins, quinones, cardiac glycosides, terpenoids, phlobatannins, anthraquinones, tannins, phenols, and flavonoids. The HPLC analysis as shown in Figure 1 confirmed the presence of these bioactive constituents in the extract
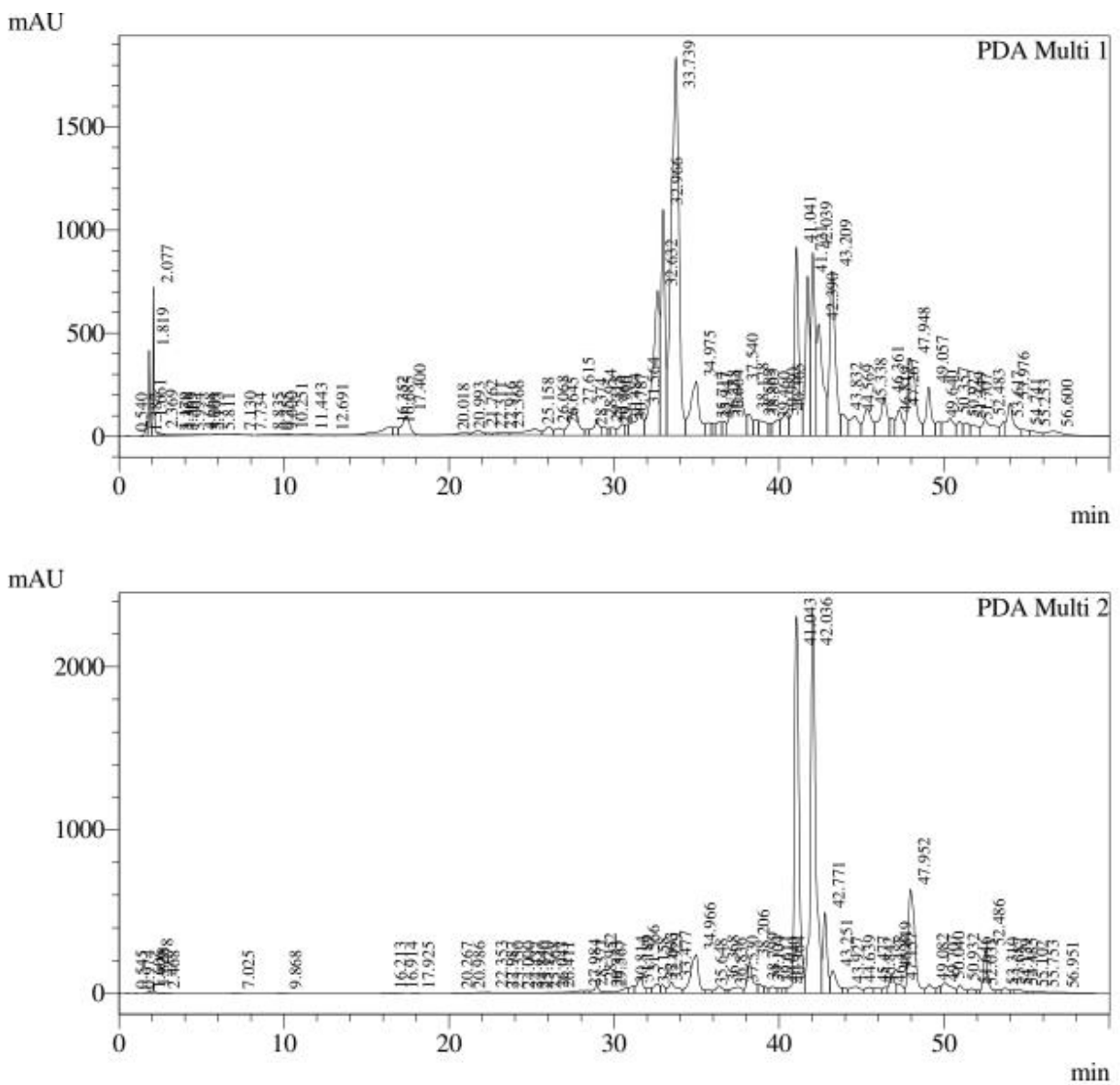

Figure 1. High performance liquid chromatogram of ethanolic extract of Glycyrrhiza glabra.

\subsection{Analysis of antioxidant activity.}

The antioxidant activity of the ethanolic extract of Glycyrrhiza glabra was determined using DPPH free radical scavenging assay. Figure 2 gives the percentage of inhibition of DPPH free radicals by different concentrations of the extract. The result indicates that the extract possesses free radical scavenging activity in a dose-dependent manner. 


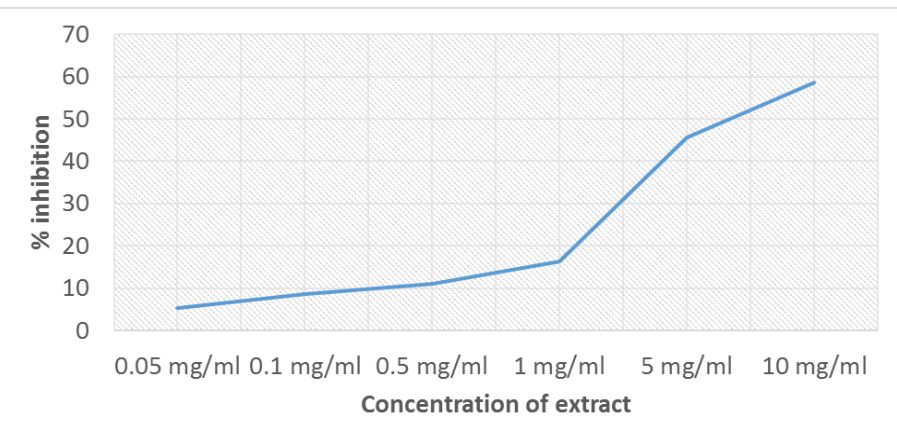

Figure 2. DPPH free radical scavenging activity of ethanolic extract of Glycyrrhiza glabra.

The antioxidant activity of the ethanolic extract of Glycyrrhiza glabra was determined using the hydroxyl radical scavenging assay. Figure 3 gives the percentage of inhibition of hydroxyl radicals by different concentrations of the extract. The result indicates that the extract possesses significant hydroxyl radical scavenging activity.

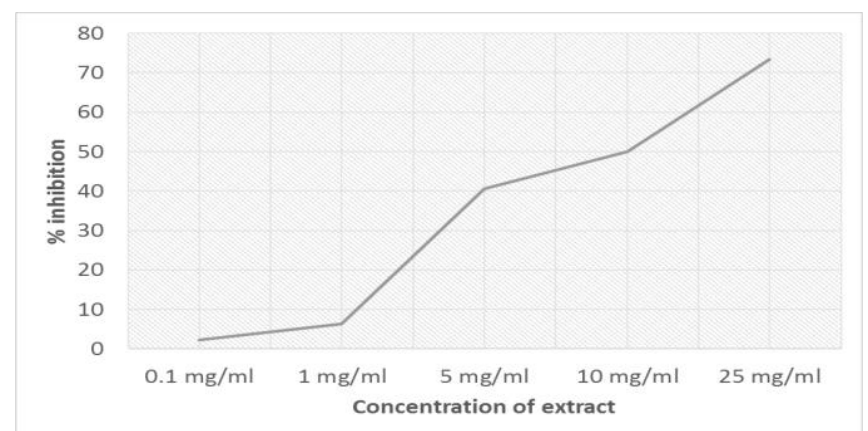

Figure 3. Hyrdoxyl radical scavenging activity of ethanolic extract of G.glabra.

The antioxidant activity of ethanolic extract of Glycyrrhiza glabra was determined using total antioxidant capacity assay. Figure 4 gives the percentage inhibition by different concentrations of the ethanolic extract.

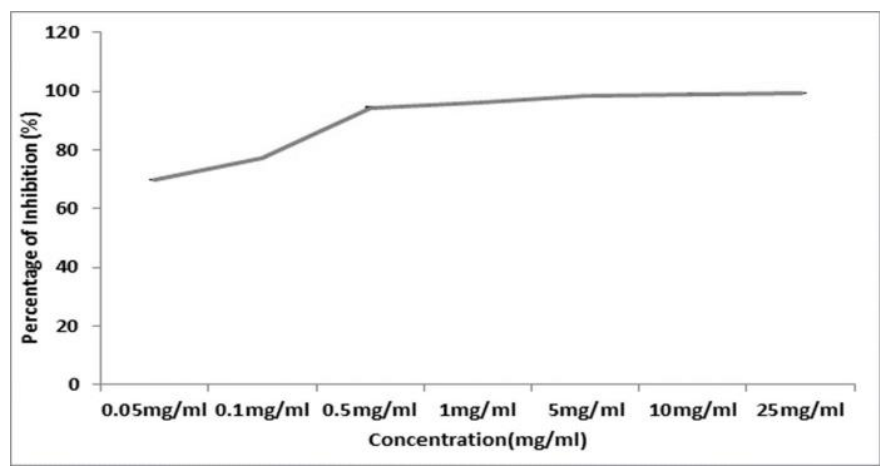

Figure 4. Total antioxidant capacity of ethanolic extract of G.glabra.

The antioxidant activity of ethanolic extract of Glycyrrhiza glabra was determined using total reducing power assay. Figure 5 gives the percentage inhibition by different concentrations of the ethanolic extract.

\subsection{Protection of tissue against oxidative stress in vitro.}

$\mathrm{H}_{2} \mathrm{O}_{2}$ is known for its oxidant activity, and it induces oxidative stress in the cells. To determine whether Glycyrrhiza glabra inhibits the $\mathrm{H}_{2} \mathrm{O}_{2}$ induced cell damage in liver tissue, GSH assay was performed by treating the cells with $1 \mathrm{mM} \mathrm{H}_{2} \mathrm{O}_{2}$. 


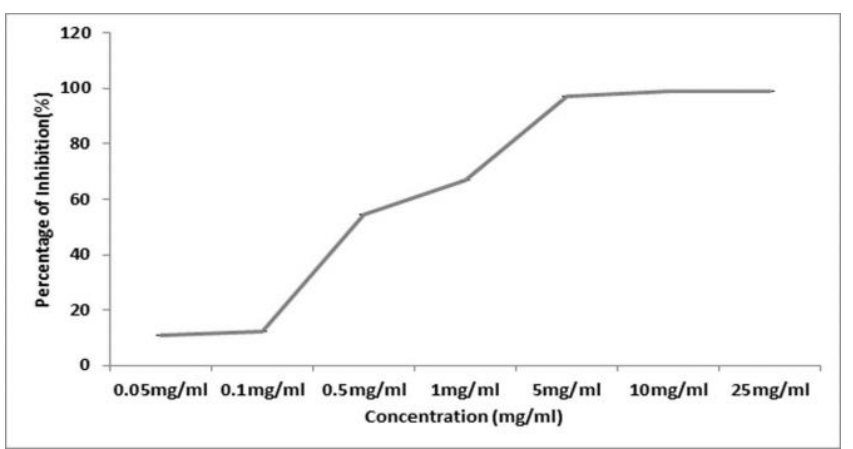

Figure 5. Total reducing power activity of ethanolic extract of G.glabra.

The results are presented in Figure 6. A significant reduction in GSH levels was found following exposure to oxidative stress. The GSH content of normal liver tissue and $\mathrm{H}_{2} \mathrm{O}_{2}$ treated control is 41.34 and 31.83 nanomoles/mg protein. It shows that the activity of GSH in the tissues studied was significantly decreased in the $\mathrm{H}_{2} \mathrm{O}_{2}$ treated control compared with normal tissue. It was also observed that Glycyrrhiza glabra treated cells showed higher glutathione as compared to only $\mathrm{H}_{2} \mathrm{O}_{2}$ treated cells where decreased glutathione was observed. The presence of Glycyrrhiza glabra and $\mathrm{H}_{2} \mathrm{O}_{2}$ restored the activities of the antioxidant enzymes and the level of glutathione to near normal compared to the corresponding $\mathrm{H}_{2} \mathrm{O}_{2}$ treated.

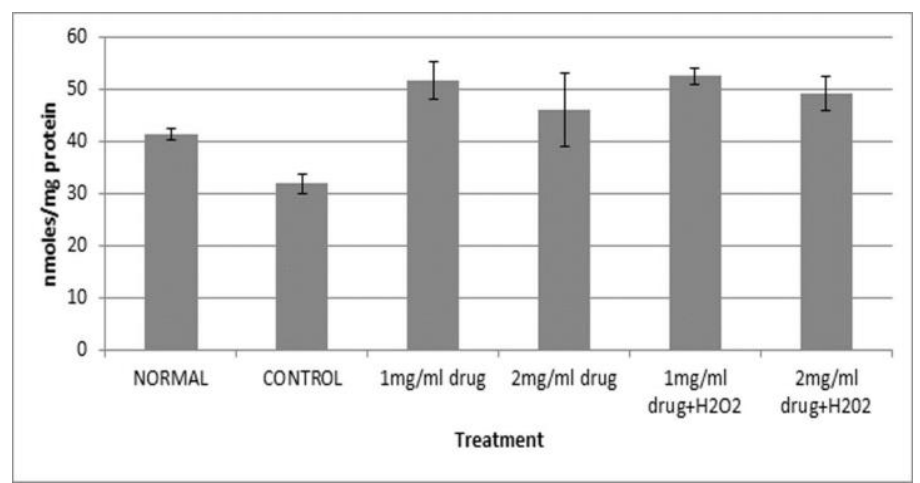

Figure 6. Levels of GSH (nanomoles/mg protein) in liver tissue homogenate treated with $1 \mathrm{mM} \mathrm{H}_{2} \mathrm{O}_{2}$ and different concentrations of Glycyrrhiza glabra extract under in vitro conditions.

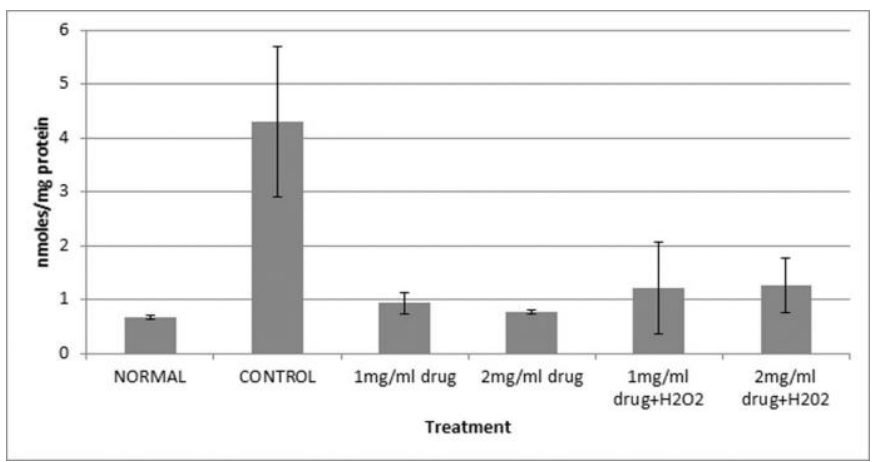

Figure 7. Extent of lipid peroxidation in liver tissue homogenate treated with $1 \mathrm{mM} \mathrm{H}_{2} \mathrm{O}_{2}$ and different concentrations of Glycyrrhiza glabra extract under in vitro conditions.

MDA is an organic compound that is the end product of the lipid peroxidation of polyunsaturated fatty acids known to induce oxidative stress. To determine whether Glycyrrhiza glabra inhibits the $\mathrm{H}_{2} \mathrm{O}_{2}$ induced cell damage in liver tissue, lipid peroxidation assay was performed by treating the cells with $1 \mathrm{Mm} \mathrm{H}_{2} \mathrm{O}_{2}$, and the results are presented in Figure 7. The Lipid peroxidation content of normal liver tissue and $\mathrm{H}_{2} \mathrm{O}_{2}$ treated control is obtained as 0.67 and 4.29 nanomoles/mg protein, respectively. The level of lipid peroxidation 
in $\mathrm{H}_{2} \mathrm{O}_{2}$ treated cells in the presence of Glycyrrhiza glabra was found to be much lower. The presence of Glycyrrhiza glabra and $\mathrm{H}_{2} \mathrm{O}_{2}$ restored the activities of the antioxidant enzymes and the level of lipid peroxidation to near normal compared to the corresponding $\mathrm{H}_{2} \mathrm{O}_{2}$ treated cells.

The levels of GSH and Lipid peroxidation indicated the potential of Glycyrrhiza glabra to protect tissue against oxidative stress induced by $\mathrm{H}_{2} \mathrm{O}_{2}$ under in vitro conditions.

\subsection{Analysis of genoprotective activity.}

Comet assay is a very useful tool that provides information regarding the extent of cellular DNA damage [13,14]. Comet assay was performed with human peripheral blood lymphocytes obtained through venipuncture. The DNA strand breaks were introduced by treatment with $1 \mathrm{mM} \mathrm{H}_{2} \mathrm{O}_{2}$ in human peripheral blood lymphocytes. The extent of DNA damage was measured using alkaline single cell gel electrophoresis. Blood was incubated with I $\mathrm{mM} \mathrm{H}_{2} \mathrm{O}_{2}$ in the presence or absence of different concentrations of Glycyrrhiza glabra extract $(1 \mathrm{mg} / \mathrm{ml}$ or $2 \mathrm{mg} / \mathrm{ml})$ for 5 minutes. After incubation, the samples were analyzed by comet assay.

In comet assay, cells embedded in agarose on a microscope slide are lysed using detergent and high salt to form nucleoids containing supercoiled loops of DNA and electrophoresed. The slides were observed under a microscope after silver staining.

When the slides were observed by microscopy after the assay, it was observed that:

a) The cells treated with $\mathrm{H}_{2} \mathrm{O}_{2}$ alone showed a -like comet appearance. The cells had an elongated tail portion, comprised of the broken fragments of the cellular DNA, which migrated out of the nucleus during the electrophoresis. This indicated the extent of DNA damage.

b) The cells treated with Glycyrrhiza glabra extract alone remained circular, indicating that the extract by itself was not genotoxic.

c) The cells treated with Glycyrrhiza glabra extract along with $\mathrm{H}_{2} \mathrm{O}_{2}$ appeared as circular discs indicating that the extract offered protection against $\mathrm{H}_{2} \mathrm{O}_{2}$ induced DNA damage.

The endogenous oxidation processes and exogenous sources produce reactive oxygen species (ROS) and free radicals. Reactive oxygen species (ROS) and reactive nitrogen species (RNS) have both beneficial and detrimental effects on the living systems. Overproduction of the free radicals induces oxidative stress culminating in biological damage. Oxidative stress caused by free radicals is involved in the onset of cancer, rheumatoid arthritis, liver cirrhosis, arteriosclerosis, and degenerative diseases related to aging $[15,16]$. Nearly all living organisms have evolved a complicated antioxidant system mainly comprised of antioxidant enzymes which include catalase (CAT), glutathione peroxidize (GSHPx), superoxide dismutase (SOD), or substances including ascorbic acid, a-tocopherol, carotenoids, glutathione, and polyphenol substances to protect the cells and organ systems. However, the production of natural antioxidants under normal physiological conditions is insufficient to prevent all damages caused. Consumption of antioxidant supplements or foods that possess antioxidative activities may reduce oxidative damage [17,18]. Several synthetic antioxidants such as Butylated hydroxyanisole (BHA), butylated hydroxytoluene (BHT), tertbutylhydroquinone (THBQ), and propyl gallate are in common use nowadays. However, several reports suggested that synthetic antioxidants promote tumor formation $[19,20]$. In this scenario, natural antioxidants received much attention and are being extensively studied. A wide range of antioxidants has been isolated from plant materials, including cereal crops, herbs, spices, vegetables, fruits, oilseeds, leaves, and roots. It is a known fact that Glycyrrhiza glabra is one of the richest sources of biologically active compounds such as phenolic and flavonoid compounds, which act as 
primary antioxidants or free radical scavengers [21]. It possess antitumor, antimicrobial, antiinflammatory, immunoregulatory activities, etc. [22,23,24]. In the present study, the antioxidant and genoprotective activity of ethanolic extract of Glycyrrhiza glabra was evaluated by various in vitro assays.

Free radical scavenging activity is a potent indicator of the bioactive compounds that can act as an effective phytotherapeutic. The DPPH antioxidant assay, Hydroxyl radical scavenging assay, the reducing power assay, and the total antioxidant capacity showed the potent antioxidant potential of Glycyrrhiza glabra extract. Glycyrrhiza glabra extract prevented oxidative damage, as shown by the level of GSH and lipid peroxidation in chicken liver tissue treated with $1 \mathrm{mM} \mathrm{H} \mathrm{H}_{2}$. The presence of Glycyrrhiza glabra along with $\mathrm{H}_{2} \mathrm{O}_{2}$ restored the level of glutathione and lipid peroxidation to near-normal levels. $\mathrm{H}_{2} \mathrm{O}_{2}$ induced DNA strand breaks in the peripheral blood lymphocytes were measured using alkaline single cell gel electrophoresis. The results revealed that Glycyrrhiza glabra extract offered protection against $\mathrm{H}_{2} \mathrm{O}_{2}$ induced cellular DNA damage.

\section{Conclusions}

Glycyrrhiza glabra extract could ameliorate $\mathrm{H}_{2} \mathrm{O}_{2}$ induced oxidative damage and cellular DNA damage under in vitro conditions, which may be due to its antioxidant and free radical scavenging properties. These findings indicated promising antioxidant and antigenotoxic potential of Glycyrrhiza glabra and need further exploration for translating these findings to its possible health benefits.

\section{Funding}

This research received no external funding.

\section{Acknowledgments}

The authors express gratitude for the student project's financial assistance from Kerala State Council for Science Technology and Environment.

\section{Conflicts of Interest}

The authors declare no conflict of interest.

\section{References}

1. Atanasov, A.G.; Waltenberger, B.; Pferschy-Wenzig, E.-M.; Linder, T.; Wawrosch, C.; Uhrin, P.; Temml, V.; Wang, L.; Schwaiger, S.; Heiss, E.H.; Rollinger, J.M.; Schuster, D.; Breuss, J.M.; Bochkov, V.; Mihovilovic, M.D.; Kopp, B.; Bauer, R.; Dirsch, V.M.; Stuppner, H. Discovery and resupply of pharmacologically active plant-derived natural products: A review. Biotechnology Advances 2015, 33, 15821614, https://doi.org/10.1016/j.biotechadv.2015.08.001.

2. Wang, L.; Yang, R.; Yuan, B.; Liu, Y.; Liu, C. The antiviral and antimicrobial activities of licorice, a widelyused Chinese herb. Acta Pharmaceutica Sinica B 2015, 5, 310-315, https://doi.org/10.1016/j.apsb.2015.05.005.

3. Pastorino, G.; Cornara, L.; Soares, S.; Rodrigues, F.; Oliveira, M.B.P.P. Liquorice (Glycyrrhiza glabra): A phytochemical and pharmacological review. Phytotherapy Research 2018, 32, 2323-2339, https://doi.org/10.1002/ptr.6178.

4. Frattaruolo, L.; Carullo, G.; Brindisi, M.; Mazzotta, S.; Bellissimo, L.; Rago, V.; Curcio, R.; Dolce, V.; Aiello, F.; Cappello, A.R. Antioxidant and Anti-Inflammatory Activities of Flavanones from Glycyrrhiza glabra L. (licorice) Leaf Phytocomplexes: Identification of Licoflavanone as a Modulator of NF-kB/MAPK Pathway. Antioxidants 2019, 8, https://doi.org/10.3390/antiox8060186. 
5. Khandelwal, K.R. Practical Pharmacognosy. Techniques and experiments. 12 th edition, Nirali, P. Publishers 2004; pp. 149-153.

6. von Gadow, A.; Joubert, E.; Hansmann, C.F. Comparison of the Antioxidant Activity of Aspalathin with That of Other Plant Phenols of Rooibos Tea (Aspalathus linearis), $\alpha$-Tocopherol, BHT, and BHA. J Agric Food Chem 1997, 45, 632-638, https://doi.org/10.1021/jf960281n.

7. Prieto, P.; Pineda, M.; Aguilar, M. Spectrophotometric Quantitation of Antioxidant Capacity through the Formation of a Phosphomolybdenum Complex: Specific Application to the Determination of Vitamin E. Analytical Biochemistry 1999, 269, 337-341, https://doi.org/10.1006/abio.1999.4019.

8. Yen, G.-C.; Duh, P.-D. Antioxidative properties of methanolic extracts from peanut hulls. Journal of the American Oil Chemists' Society 1993, 70, 383-386, https://doi.org/10.1007/BF02552711.

9. Moron, M.S.; Depierre, J.W.; Mannervik, B. Levels of glutathione, glutathione reductase and glutathione Stransferase activities in rat lung and liver. Biochimica et Biophysica Acta (BBA) - General Subjects 1979, 582, 67-78, https://doi.org/10.1016/0304-4165(79)90289-7).

10. Buege, J.A.; Aust, S.D. Microsomal lipid peroxidation. Methods Enzymol 1978, 52, 302-310, https://doi.org/10.1016/S0076-6879(78)52032-6.

11. Lowry, O.H.; Rosebrough, N.J.; Farr, A.L.; Randall, R.J. Protein measurement with the Folin phenol reagent. J Biol Chem 1951, 193, 265-275.

12. Singh, N.P. Microgels for estimation of DNA strand breaks, DNA protein crosslinks and apoptosis. Mutation Research/Fundamental and Molecular Mechanisms of Mutagenesis 2000, 455, 111-127, https://doi.org/10.1016/s0027-5107(00)00075-0.

13. Vilchez-Aruani, J.; Cuello-Carrión, F.D.; Valdez, S.R.; Nadin, S.B. Genomic effects of a nanostructured alumina insecticide in human peripheral blood lymphocytes in vitro. Heliyon 2020, 6 , https://doi.org/10.1016/j.heliyon.2020.e04216.

14. Siew, E.L.; Farris, A.F.; Rashid, N.; Chan, K.M.; Rajab, N.F. In vitro toxicological assessment of gadolinium (III) chloride in V79-4 fibroblasts. Genes and Environment 2020, 42, https://doi.org/10.1186/s41021-02000161-3.

15. Phaniendra, A.; Jestadi, D.B.; Periyasamy, L. Free Radicals: Properties, Sources, Targets, and Their Implication in Various Diseases. Indian Journal of Clinical Biochemistry 2015, 30, 11-26, https://doi.org/10.1007/s12291-014-0446-0.

16. Poprac, P.; Jomova, K.; Simunkova, M.; Kollar, V.; Rhodes, C.J.; Valko, M. Targeting Free Radicals in Oxidative Stress-Related Human Diseases. Trends in Pharmacological Sciences 2017, 38, 592-607, https://doi.org/10.1016/j.tips.2017.04.005.

17. Neha, K.; Haider, M.R.; Pathak, A.; Yar, M.S. Medicinal prospects of antioxidants: A review. European Journal of Medicinal Chemistry 2019, 178, 687-704, https://doi.org/10.1016/j.ejmech.2019.06.010.

18. Tan, B.L.; Norhaizan, M.E.; Liew, W.-P.-P.; Sulaiman Rahman, H. Antioxidant and Oxidative Stress: A Mutual Interplay in Age-Related Diseases. 2018, 9, https://doi.org/10.3389/fphar.2018.01162.

19. Taghvaei, M.; Jafari, S.M. Application and stability of natural antioxidants in edible oils in order to substitute synthetic additives. Journal of Food Science and Technology 2015, 52, 1272-1282, https://doi.org/10.1007/s13197-013-1080-1.

20. Yang, X.; Sun, Z.; Wang, W.; Zhou, Q.; Shi, G.; Wei, F.; Jiang, G. Developmental toxicity of synthetic phenolic antioxidants to the early life stage of zebrafish. Science of The Total Environment 2018, 643, 559568, https://doi.org/10.1016/j.scitotenv.2018.06.213.

21. Martins, N.; Barros, L.; Dueñas, M.; Santos-Buelga, C.; Ferreira, I.C.F.R. Characterization of phenolic compounds and antioxidant properties of Glycyrrhiza glabra L. rhizomes and roots. RSC Advances 2015, 5, 26991-26997, https://doi.org/10.1039/C5RA03963K.

22. Batiha, G E.; Beshbishy, A.M.; El-Mleeh, A.; Abdel-Daim, M.M.; Devkota, H.P. Traditional Uses, Bioactive Chemical Constituents, and Pharmacological and Toxicological Activities of Glycyrrhiza glabra L. (Fabaceae). Biomolecules, 2020, 10, 352, https://doi.org/10.3390/biom10030352.

23. Zhang, B.; Yan, M.; Zhang, W.; Ke, Z.Y.; Ma, L.G. Glycyrrhiza glabra suppresses nasopharyngeal carcinoma cell proliferation through inhibiting the expression of lncRNA, AK027294. Biosci Biotechnol Biochem, 2020, 84, 314-320, https://doi.org/10.1080/09168451.2019.1673695.

24. Malvania, E.A.; Sharma, A.S.; Sheth, S.A.; Rathod, S.; Chovatia, N.R.; Kachwala, M.S. In Vitro Analysis of Licorice ( Glycyrrhiza glabra) Root Extract Activity on Streptococcus mutans in Comparison to Chlorhexidine and Fluoride Mouthwash, J Contemp Dent Pract. 2019, 20, 1389-1394. 